\title{
Diurnal Changes in Lipolytic Activity of Isolated Fat Cells and Their Increased Responsiveness to Epinephrine and Theophylline with Meal Feeding in Rats
}

\author{
Masashige SuzuKI, ${ }^{1, *}$ Yoshiharu ShImomura, ${ }^{2}$ and Yuji SATOH ${ }^{3}$ \\ ${ }^{1}$ Biochemistry of Exercise and Nutrition, Institute of Health \\ and Sports Sciences, University of Tsukuba, Sakura-mura, \\ Niihari-gun, Ibaraki 305, Japan
}

(Received October 25, 1982)

\begin{abstract}
Summary Diurnal changes in glycogen stores of adipose tissues and in vitro lipolytic activity of isolated epididymal fat cells, and their lipolytic responsiveness to epinephrine and theophylline were examined in rats adapted to a 2-h daily meal feeding (20.00-22.00 h; darkness between $20.00-08.00 \mathrm{~h}$ ) for 3 weeks and in control rats fed ad libitum. The fat cells from both groups of animals showed the peak of lipolytic activity at the mid-dark period $(03.00 \mathrm{~h})$, but the peak values and the average values at 6 or 7 time points examined within the 24 -h feeding cycle were significantly higher $(p<0.025)$ in meal-fed rats. Basal, epinephrine-stimulated, and epinephrine-induced lipolysis of fat cells from control rats showed diurnal changes, and the rhythms and their amplitude were affected by meal feeding. Changes in lipolytic activity of fat cells did not seem to relate directly to those of glycogen stores in adipose tissue. The over-all 24-h means of lipolytic activity of fat cells were significantly increased $(p<0.001)$ with meal feeding. Mean cell size of epididymal fat pads was significantly smaller $(p<0.001)$ in meal-fed rats, but lipolytic responsiveness to the graded concentrations of epinephrine and theophylline in the incubation medium was significantly greater $(p<0.001)$ in meal-fed rats than in rats fed ad libitum. Thus, these findings suggest that lipolytic activity of the cAMP-hormone sensitive lipase system in fat cells might be increased with meal feeding in rats. Furthermore, the present results may give a new idea to consider the discrepancy that many workers have not been able to observe the increase in body fat deposition with meal feeding,
\end{abstract}

${ }^{1}$ 鈴木正成, ${ }^{2}$ 下村吉治, ${ }^{3}$ 佐藤雄二

${ }^{2}$ Present address: The Second Division of Department of Biochemistry, School of Medicine, Nagoya University, Showa-ku, Nagoya, Aichi 466, Japan

${ }^{3}$ Present address: Institute of Clinical Medicine, University of Tsukuba, Sakura-mura, Niihari-gun, Ibaraki 305, Japan

* To whom correspondence should be addressed. 
which has been frequently reported to enhance lipogenesis in rats.

Key Words meal feeding, diurnal change, adipose tissue glycogen, lipolytic activity of fat cell, responsiveness to epinephrine and theophylline

Lipogenesis in rat adipose tissue has been reported to be enhanced by meal feeding $(1)$ and diurnal changes in lipogenesis have been suggested $(2,3)$. With respect to the effect of meal feeding on lipolysis, however, only a few studies have been conducted with rats allowed access to unlimited food for 2-h each day. Leveille (4) observed the decrease in FFA concentrations in the adipose tissue, whereas glycogen was accumulated, in meal fed rats. Ip et al.(5) indicated that the level of cyclic-adenosine monophosphate (cAMP) in the adipose tissue of meal-fed rats exhibited diurnal changes with a sharp decrease after meal ingestion. In addition, Braun et al. $(6,7)$ demonstrated that the in vitro lipolytic effect of epinephrine on the adipose tissue was increased in meal-fed rats. However, diurnal changes in lipolysis have not been determined.

The present report describes the diurnal changes of in vitro lipolytic activity of isolated epididymal fat cells from meal-fed rats. This study also deals with the effect of meal feeding on the lipolytic responsiveness of fat cells to epinephrine and theophylline as well as on the distribution of fat cell size.

\section{EXPERIMENTAL}

Four weeks old male rats of the JCL-Sprague-Dawley strain (CLEA Japan Inc., Tokyo) were used for all studies. The animals were housed individually in cages in a temperature-regulated room $\left(23^{\circ} \mathrm{C}\right)$ with light on from 08.00 to $20.00 \mathrm{~h}$. At the initiation of the study the animals were divided at random into 2 groups. One group was fed ad libitum, and the other group, the meal-fed group, was allowed free access to food for only $2 \mathrm{~h}(20.00-22.00 \mathrm{~h})$ each day. The meal feeding was automatically conducted using Suzuki-Imamura's Automated Feeding System (CLEA Japan Inc.) (8). Water was freely given at all times and body weight was determined every day. Animals were fed a commercial diet (CE 7 powder, CLEA Japan Inc.), and the food consumption was measured on days indicated in the results.

In experiment 1, 62 rats (30 ad libitum fed and 32 meal-fed) were used and, at the end of the 3-week feeding, 4-5 rats of both groups were killed by decapitation at $19.00,21.00$ (only meal-fed rats), 23.00, 03.00, 07.00, 11.00 and $15.00 \mathrm{~h}$ within $24 \mathrm{~h}$. Right epididymal fat pads were removed, digested with collagenase (Type 1, Worthington Biochemical Co., Freehold) and prepared for fat cells according to the method by Rodbell $(9,10)$. Then the fat cells, which were suspended in the KrebsRinger phosphate buffer containing $4 \%$ bovine serum albumin (Fraction V, fatty acid-free, Sigma Co., St. Louis), pH 7.4, were incubated for $60 \mathrm{~min}$ at $37^{\circ} \mathrm{C}$ with or without L-epinephrine-D-hydrogentartarate (Fluka Co., Buchs) at the concentration of $1 \mu \mathrm{g}$ epinephrine per $\mathrm{ml}(9)$. FFA (11) and glycerol(12) concentrations in the 
medium were determined at the end of incubation, and protein (13) contents of fat cells before incubation were also determined. Lipolytic activity of fat cells was expressed as $\mu \mathrm{mol}$ glycerol or FFA released $/ \mathrm{h} / \mathrm{mg}$ fat cell protein. The activities obtained without and with epinephrine were termed as basal lipolysis and epinephrine-stimulated lipolysis, respectively. Furthermore, difference between both activities was termed as epinephrine-induced lipolysis. Serum glucose (14) and FFA (11) levels and glycogen(14) contents in liver and epididymal, perirenal, mesenteric and subcutaneous adipose tissues were also determined.

In experiment 2, 20 rats (10 rats for ad libitum fed and meal-fed groups each) were used. At the end of the 3-week feeding, 5 rats of both groups were killed by decapitation at 10.00 and $22.00 \mathrm{~h}$, and right epididymal fat pads were removed for isolation of fat cells as described above. Lipolytic responses to epinephrine $\left(0,10^{-7}\right.$, $10^{-6}, 5 \times 10^{-6}$, and $\left.10^{-5} \mathrm{M}\right)$ and theophylline $\left(0,7.5 \times 10^{-4}, 10^{-3}, 7.5 \times 10^{-3}\right.$, and $10^{-2} \mathrm{M}$ : Wako Pure Chemicals Ind. Ltd., Tokyo) added to the incubation medium were determined by measurement of glycerol(15) released during the $60-\mathrm{min}$ incubation. The lipolytic activity was expressed as $\mu \mathrm{mol}$ glycerol released $/ \mathrm{h} / 10^{6}$ fat cells. Number and size of fat cells were measured microscopically after staining fat cells with methylene blue.

The significance of the difference between two means has been assessed on the basis of Student's $t$-test.

\section{RESULTS}

\section{Experiment 1}

Food intake, weight gain, and liver and adipose tissue weight (Table 1). Mealfed rats showed a weight loss during the first 6-day period of adaptation to meal feeding. Food intake and weight gain of meal-fed rats were considerably small throughout the 3-week feeding period, and the final body weight of meal-fed rats was significantly lower than that of rats fed ad libitum $(p<0.001)$. Weight of liver and epididymal fat pads was also significantly lower in meal-fed rats $(p<0.001)$.

Diurnal changes in serum glucose and FFA levels (Fig. 1, Table 2). Except for a sharp rise between 11.00 to $15.00 \mathrm{~h}$ in meal-fed rats, the serum glucose of both groups of rats showed similar diurnal changes. But, the levels in meal-fed rats were lower than those in control rats throughout the 24-h feeding cycle, resulting in a significantly lower over-all $24-\mathrm{h}$ mean in meal-fed rats $(p<0.005)$. Serum FFA concentrations decreased sharply with feeding in meal-fed rats, and those of both groups showed similar rhythmicity with the bottom level at the mid-dark period. There was no significant difference in the over-all 24-h mean of serum FFA levels between the two groups of rats.

Diurnal changes in liver and adipose tissue glycogen contents (Fig. 2, Table 2). Rats fed ad libitum did not show any significant changes in liver glycogen contents throughout the 24-h feeding cycle. Contrarily, in meal-fed rats, liver glycogen contents rapidly decreased during the 2 -h meal feeding period, then increased 
Table 1. Weight gain, liver and epididymal fat pad weight, and food intake of ad libitum fed and meal-fed rats (experiment 1).

\begin{tabular}{|c|c|c|c|c|}
\hline \multirow{2}{*}{ Variables } & & \multicolumn{2}{|c|}{ Feeding pattern } & \multirow{2}{*}{$\begin{array}{c}\text { Meal-fed/ } \\
\text { Ad libitum } \\
\quad(\%)\end{array}$} \\
\hline & & Ad libitum & Meal-fed & \\
\hline \multirow{4}{*}{$\begin{array}{l}\text { Body weight: Initial (g) } \\
\text { Gain (g/rat/day) }\end{array}$} & & $84.9 \pm 0.6$ & $85.0 \pm 0.4$ & 100 \\
\hline & $0-6$ day & $7.8 \pm 0.1$ & $0.4 \pm 0.1^{\mathrm{a}}$ & 5.1 \\
\hline & 6-14 day & $7.5 \pm 0.1$ & $4.1 \pm 0.1^{\mathrm{a}}$ & 54.7 \\
\hline & 14-21 day & $7.3 \pm 0.2$ & $4.8 \pm 0.1^{\mathrm{a}}$ & 65.8 \\
\hline $\begin{array}{l}\text { Final }(\mathrm{g}) \\
\end{array}$ & & $242.8 \pm 2.9$ & $153.1 \pm 2.0^{\mathrm{a}}$ & 63.1 \\
\hline Liver weight $(\mathrm{g})$ & & $13.0 \pm 0.2$ & $7.1 \pm 0.2^{\mathrm{a}}$ & 54.6 \\
\hline Epididymal fat pad weight (g) & & $1.93 \pm 0.05$ & $0.89 \pm 0.03^{\mathrm{a}}$ & 46.1 \\
\hline \multirow[t]{6}{*}{ Food intake $(\mathrm{g} / \mathrm{rat} /$ day $)$} & 5- 7 day & $17.7 \pm 0.3$ & $8.1 \pm 0.2^{\mathrm{a}}$ & 45.8 \\
\hline & $12-14$ day & $21.2 \pm 0.3$ & $11.7 \pm 0.2^{\mathrm{a}}$ & 55.2 \\
\hline & 19-20 day & $23.0 \pm 0.4$ & $12.9 \pm 0.1^{\mathrm{a}}$ & 56.1 \\
\hline & 5- 7 day & $13.5 \pm 0.1$ & $9.9 \pm 0.1^{\mathrm{a}}$ & 68.9 \\
\hline & $12-14$ day & $11.6 \pm 0.1$ & $10.3 \pm 0.1^{\mathrm{a}}$ & 88.8 \\
\hline & 19-20 day & $10.0 \pm 0.1$ & $8.8 \pm 0.1^{\mathrm{a}}$ & 88.0 \\
\hline
\end{tabular}

Values are means \pm SEM for 30 ad libitum fed and 32 meal-fed rats. Food intake was measured at the indicated days of experimental period. ${ }^{\text {a }}$ Significantly different $(p<0.001)$ from ad libitum fed rats.

significantly and maintained a relatively high level from 03.00 to $11.00 \mathrm{~h}$. The overall 24-h mean of liver glycogen level was significantly low in meal-fed rats as compared with those in controls.

Glycogen levels in four adipose tissues showed quite similar diurnal changes with the peak level at $03.00 \mathrm{~h}$ in both groups of rats, but at 23.00 and $03.00 \mathrm{~h}$ the glycogen stores in meal-fed rats were considerably higher than those in rats fed ad libitum. As compared to rats fed ad libitum, the peak value (mean \pm SEM) in the meal-fed rats was significantly higher in subcutaneous $(2,513 \pm 423 \mu \mathrm{g} / \mathrm{g}, p<0.001)$, mesenteric $(2,849 \pm 626, p<0.005)$ and perirenal $(4,491 \pm 1,020, p<0.001)$ adipose tissues, but it was not significantly different in epididymal adipose tissue $(1,728 \pm 718)$. In meal-fed rats, perirenal adipose tissue showed a two-fold higher peak of glycogen store as compared with the other three adipose tissues. The overall 24-h mean of glycogen stores in meal-fed rats was significantly higher in subcutaneous, mesenteric and perirenal adipose tissues, than those in rats fed ad libitum, but this was not true for epididymal adipose tissue.

Diurnal changes in basal, epinephrine-stimulated, and epinephrine-induced lipolytic activity of isolated epididymal fat cells (Fig. 3, Table 2). It was found that in both ad libitum and meal-fed groups of rats, there was a significant $(p<0.05)$ difference between peak and bottom values of either basal or epinephrine-stimulated glycerol release rates of epididymal fat cells. Rhythmicity of basal glycerol release 


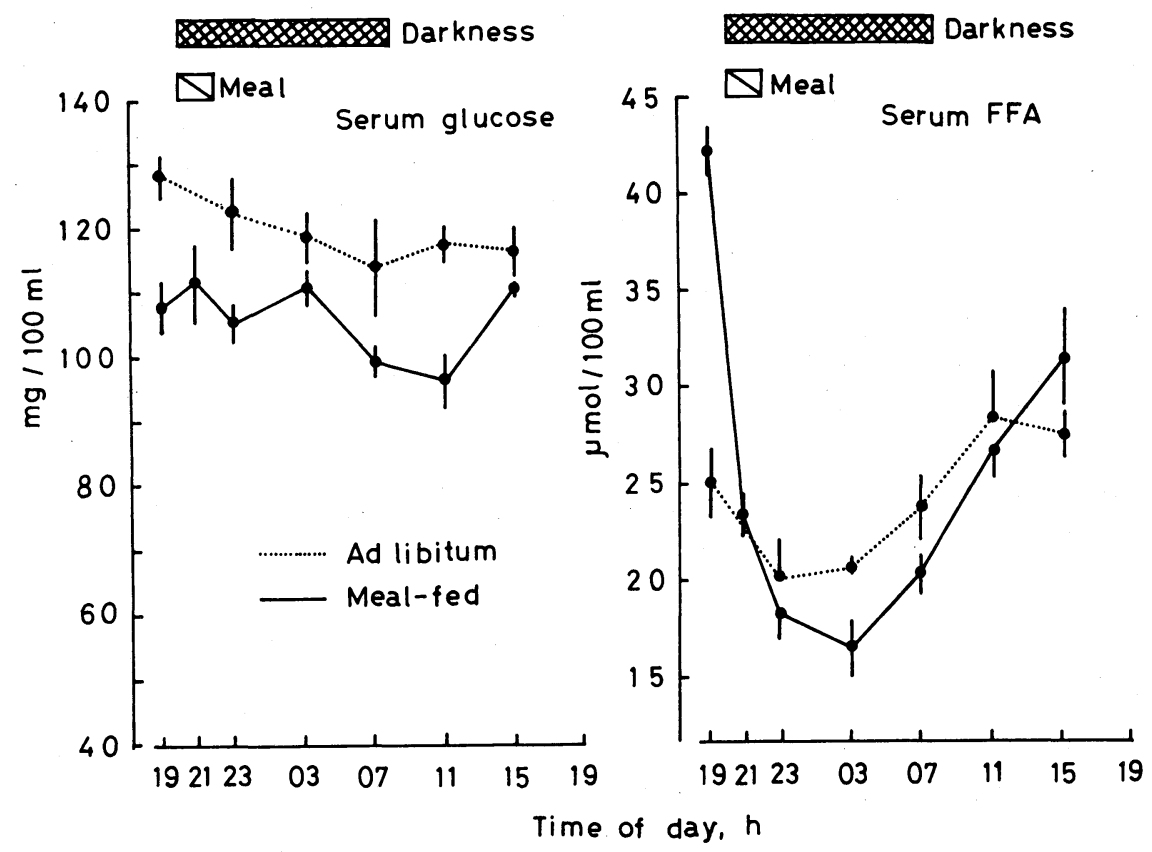

Fig. 1. Diurnal changes in serum glucose and FFA levels of ad libitum fed and meal-fed rats (experiment 1). Meal, meal time for meal-fed rats. Each point and vertical line represent mean and SEM for 4-5 rats of each group, respectively.

and epinephrine-stimulated glycerol and FFA release by isolated fat cells was generally equal in each experimental group, but it was significantly different between ad libitum fed and meal-fed rats. Basal and epinephrine-stimulated glycerol release in fat cells from rats fed ad libitum was relatively high through the later half of the dark period to the earlier half of the light period. Contrarily, in fat cells from meal-fed rats basal and epinephrine-stimulated glycerol release showed a trough at $11.00 \mathrm{~h}$ and a peak $1-\mathrm{h}$ after the ending of the meal. The peak appeared following a slight decline during the meal time and was followed by a large decline. Fat cells from both groups of rats showed similar diurnal changes in epinephrine-induced glycerol release. Basal glycerol release and epinephrine-stimulated glycerol and FFA release as well as epinephrine-induced glycerol release were considerably higher in fat cells from meal-fed rats at most of the time points indicated, resulting in the significantly greater over-all 24 -h mean of any lipolytic parameter $(p<$ 0.001 ) in fat cells from meal-fed rats than in those from rats fed ad libitum.

\section{Experiment 2}

Distribution of cell size of epididymal fat cells and their lipolytic responsiveness to epinephrine and theophylline (Fig. 4). In experiment 1, rates of glycerol release Vol. 29, No. 4, 1983 
Table 2. Over-all 24-h means of serum glucose and FFA levels, liver and adipose tissue glycogen levels, and lipolytic activity of isolated epididymal fat cells in ad libitum fed and meal-fed rats (experiment 1).

\begin{tabular}{|c|c|c|c|}
\hline \multirow{2}{*}{ Variables } & \multicolumn{2}{|c|}{ Feeding pattern } & \multirow{2}{*}{$\begin{array}{l}\text { Meal-fed/ } \\
\text { Ad libitum } \\
\quad(\%)\end{array}$} \\
\hline & Ad libitum & Meal-fed & \\
\hline Serum glucose $(\mathrm{mg} / 100 \mathrm{ml})$ & $120.4 \pm 2.3$ & $105.9 \pm 1.7^{\mathrm{b}}$ & 88.0 \\
\hline Serum FFA $(\mu \mathrm{mol} / 100 \mathrm{ml})$ & $24.61 \pm 0.99$ & $25.52 \pm 1.75$ & 103.7 \\
\hline Liver glycogen $(\mathrm{mg} / \mathrm{g})$ & $35.0 \pm 1.5$ & $29.6 \pm 2.7$ & 84.6 \\
\hline (mg/whole liver) & $456.9 \pm 22.3$ & $222.4 \pm 21.4^{\mathrm{c}}$ & 48.7 \\
\hline \multicolumn{4}{|l|}{ Adipose tissue glycogen } \\
\hline Subcutaneous $(\mu \mathrm{g} / \mathrm{g})$ & $40.3 \pm 11.3$ & $554.4 \pm 178.5^{\mathrm{c}}$ & $1,376.7$ \\
\hline Mesenteric $(\mu \mathrm{g} / \mathrm{g})$ & $133.5 \pm 33.1$ & $640.9 \pm 198.6^{a}$ & 480.1 \\
\hline Perirenal $(\mu \mathrm{g} / \mathrm{g})$ & $180.7 \pm 43.3$ & $916.3 \pm 310.5^{\mathrm{a}}$ & 507.1 \\
\hline Epididymal $(\mu \mathrm{g} / \mathrm{g})$ & $156.0 \pm 37.6$ & $330.4 \pm 130.7$ & 211.8 \\
\hline$(\mu \mathrm{g} /$ fat pads $)$ & $312.6 \pm 85.9$ & $287.8 \pm 115.4$ & 92.1 \\
\hline \multirow{2}{*}{\multicolumn{4}{|c|}{$\begin{array}{l}\text { Lipolytic activity of the cells }{ }^{1} \\
(\mu \mathrm{mol} / \mathrm{h} / \mathrm{mg} \text { fat cell protein }) \\
\text { Glycerol release }\end{array}$}} \\
\hline & & & \\
\hline Basal & $1.62 \pm 0.09$ & $2.20 \pm 0.11^{\mathrm{c}}$ & 135.8 \\
\hline Epinephrine-stimulated & $4.12 \pm 0.16$ & $5.63 \pm 0.21^{\mathrm{c}}$ & 137.3 \\
\hline Epinephrine-induced & $2.48 \pm 0.13$ & $3.43 \pm 0.14^{\mathrm{c}}$ & 138.3 \\
\hline Epinephrine-stimulated FFA release & $7.03 \pm 0.39$ & $10.49 \pm 0.39^{\mathrm{c}}$ & 149.0 \\
\hline
\end{tabular}

\footnotetext{
${ }^{1}$ See legend to Fig. 3. Values are means \pm SEM for $30 \mathrm{ad}$ libitum fed and 32 meal-fed rats. ${ }^{\text {a,b,c }}$ Significantly different (a, $\left.p<0.025 ; \mathrm{b}, p<0.005 ; \mathrm{c}, p<0.001\right)$ from ad libitum fed rats.
}

measured at about $5 \times 10^{-6} \mathrm{M}$ epinephrine were slightly different between fat cells obtained at $10.00 \mathrm{~h}$ and those at $22.00 \mathrm{~h}$. However, in experiment 2, isolated fat cells from rats killed at 10.00 and $22.00 \mathrm{~h}$ did not show any significant difference in cell size distribution and in lipolytic responsiveness to epinephrine and theophylline of several concentrations in every experimental group, consequently data at the two time points were combined per group. Meal-fed rats had smaller epididymal fat cells than rats fed ad libitum, and difference between the mean cell sizes in two groups of rats $(61.3 \pm 0.6 \mu \mathrm{m}$ for rats fed ad libitum and $51.2 \pm 0.5 \mu \mathrm{m}$ for meal-fed rats) was significant $(p<0.001)$. Lipolytic responsiveness of fat cells on the cell number basis to either epinephrine or theophylline, which was added to the incubation medium at the graded concentrations, was significantly increased with meal feeding $(p<0.001)$.

\section{DISCUSSION}

The present study clearly showed the lowered serum glucose levels in meal-fed rats, being not in accord with the result of Philippens et al. (10) but consistent with 


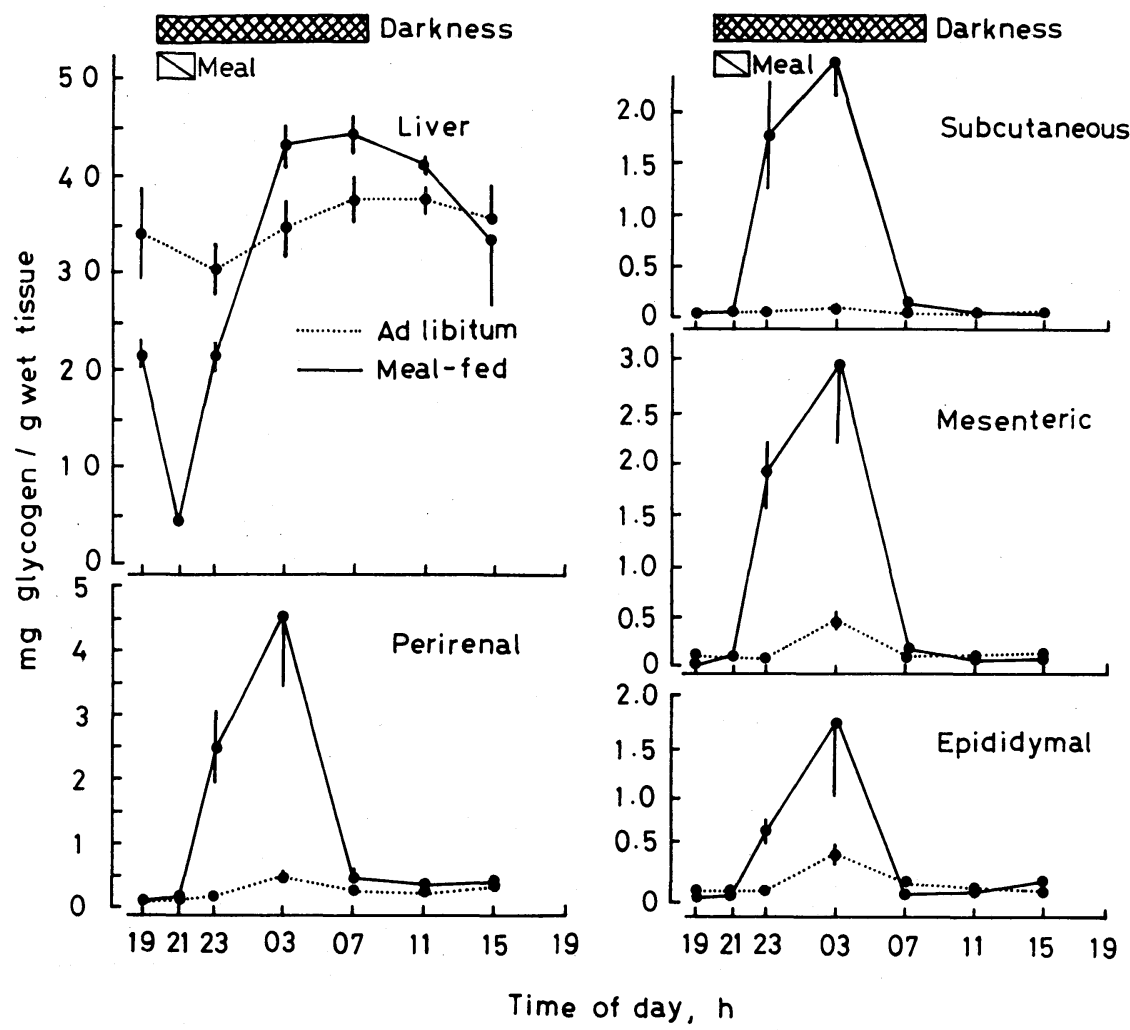

Fig. 2. Diurnal changes in glycogen levels in liver and adipose tissues of ad libitum fed and meal-fed rats (experiment 1). Meal, meal time for meal-fed rats. Each point and vertical line represent mean and SEM for 4-5 rats of each group, respectively.

that of Ip et al. (5). This decrease with meal feeding has been due to either increased glucose tolerance (17) or elevated insulin sensitivity of peripheral tissues (18-20). In ad libitum fed rats, serum glucose concentrations elevated during 15.00 to $19.00 \mathrm{~h}$ but fell thereafter. We have previously observed a high food intake during the final 2 -h of the light period in ad libitum fed rats(21), which might stimulate insulin secretion and subsequently enhance serum glucose uptake by peripheral tissues.

Leveille and Chakrabarty(2) and Philippens et al.(16) did not observe any decrease in liver glycogen store during meal feeding time. In contrast, we found a rapid disappearance of liver glycogen store in meal-fed rats during the 2-h feeding. The similar reduction in liver glycogen store with meal feeding has been previously reported(22-25). A mobilization of liver glycogen for energy needed for dietinduced thermogenesis $(22,26)$ or for protein synthesis $(23)$ has been proposed as a possible mechanism responsible for this. Langhans et al.(27) have also recently reported a prandial hepatic glycogenolysis in rats and discussed its possible role in the production of meal ending satiety. 


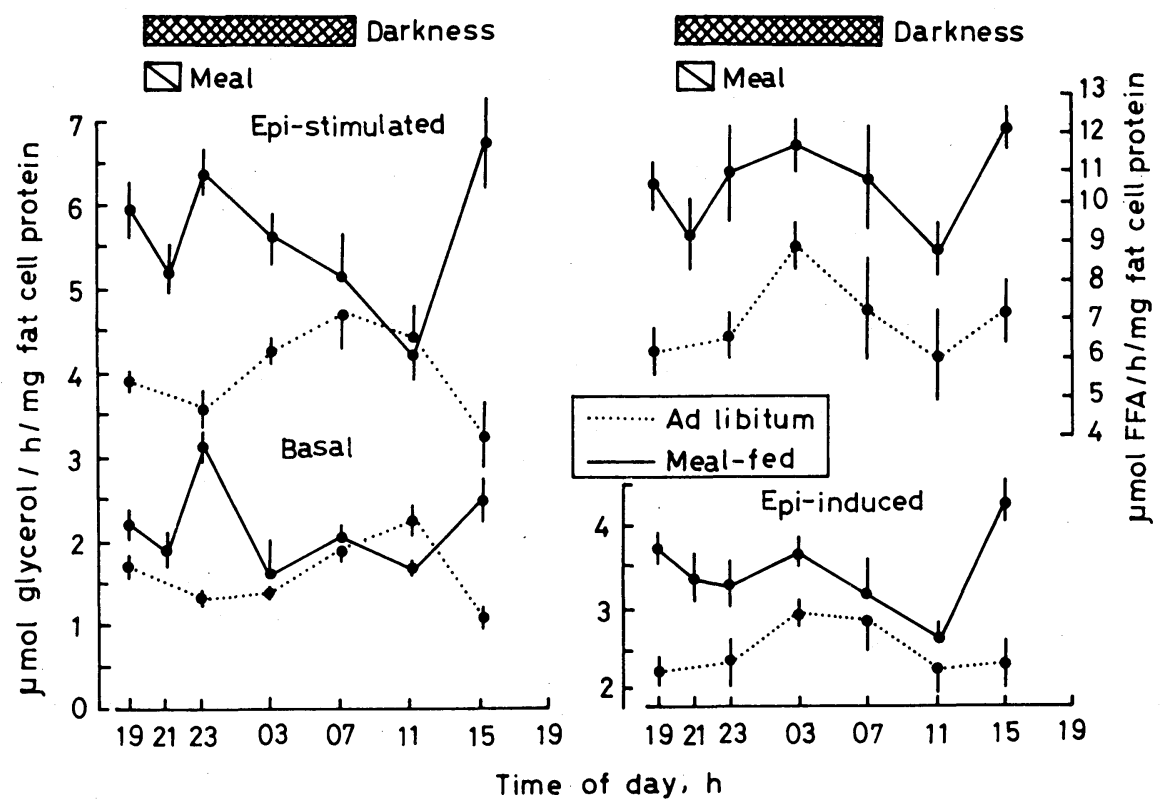

Fig. 3. Diurnal changes in lipolytic activity of isolated epididymal fat cells from ad libitum fed and meal-fed rats (experiment 1). Meal, meal time for meal-fed rats. Medium glycerol and FFA were measured at the end of 60-min incubation. Epi, epinephrine. Basal and epinephrine-stimulated lipolysis were determined without and with addition of $1.0 \mu \mathrm{g}$ epinephrine per $\mathrm{ml}$ incubation medium, respectively. Epinephrine-induced glycerol release, (epinephrine-stimulated - basal) glycerol release. Each point and vertical line represent mean and SEM for 4-5 rats of each group, respectively.

As compared with rats fed ad libitum, the greater storage of glycogen in adipose tissues of meal-fed rats in this study is similar to the earlier results reported by Leveille and co-workers $(2,4,28,29)$. Diurnal changes in glycogen store in epididymal adipose tissue of meal-fed rats were also generally consistent with that reported by Leveille and Chakrabarty (2) and, furthermore, the rhythm coincided with that of the other three adipose tissues. In adipose tissue, inactivation of glycogen synthetase and activation of phosphorylase have been reported to be mediated with elevated cAMP levels (30). Ip et al. (5) have reported that adipose tissue cAMP levels in meal-fed rats were extremely decreased with increases in food consumption. Thus, these might be partly responsible for the present observation that a significant increase in glycogen accumulation occurred in adipose tissues after meal ingestion.

This study presented the first observation for diurnal changes in lipolytic activity of isolated fat cells from rats fed ad libitum and meal-fed rats. Changes in amplitude and a shift of lipolytic activity peak occurred with meal feeding. Thus, 

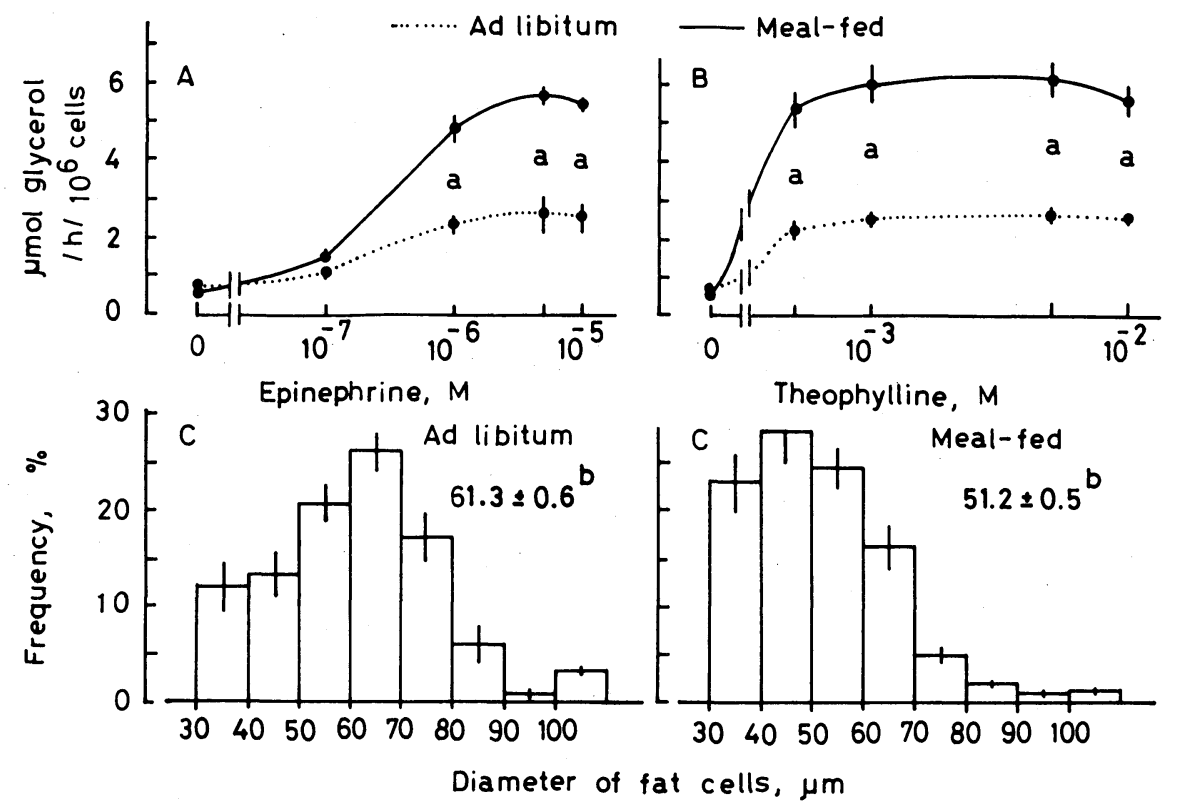

Theophylline, $M$

Fig. 4. Lipolytic responsiveness to epinephrine (A) and theophylline (B) and distribution of cell size (C) in isolated epididymal fat cells from ad libitum fed and mealfed rats (experiment 2). Each point or bar of column and vertical line respectively represent mean and SEM for 5 rats of each group. ${ }^{a}$ Significant difference $(p<0.001) .{ }^{\mathrm{b}}$ Total mean \pm SEM for 5 rats of each group and the difference between ad libitum fed and meal-fed rats is significant $(p<0.001)$.

lipolysis rhythm of fat cells is much influenced by feeding pattern. In addition, the finding of this study that epinephrine-induced lipolysis exhibited diurnal fluctuation suggests a possible existence of diurnal changes in responsiveness of fat cells to epinephrine. It is not clear what mechanism(s) might regulate the lipolysis rhythm of fat cells, but changes in the activity of adenylate cyclase (31-33) and cAMP levels (5) in adipose tissue may be responsible in part.

$\alpha$-Glycerophosphate ( $\alpha-\mathrm{GP})$, which enhances the esterification of the liberated FFA and subsequently reduces FFA levels in fat cells and FFA release into circulation, might be related to diurnal changes in the FFA release. The synthesis rate of $\alpha$-GP may be increased while glycogen store is high in adipose tissue (34). Leveille (4) has reported an increase in accumulation of glycogen with a concomitant decrease in FFA levels in adipose tissue of meal-fed rats. In the present study, however, epinephrine-stimulated FFA release by fat cells in both rats fed ad libitum and meal-fed rats was relatively high at $03.00 \mathrm{~h}$, when a high glycogen store and a low apparent FFA reesterification (theoretical FFA release-actual FFA release; data were not shown) were concomitantly occurring in fat cells of both groups of rats. Thus, the rate of glycerol release by fat cells is not always followed by that of

Vol. 29, No. 4, 1983 
FFA release, which might explain the discrepancy in fat cells from rats fed ad libitum in which the glycerol release was relatively high at $11.00 \mathrm{~h}$ but FFA release was low. The diurnal changes in epinephrine-stimulated FFA release by fat cells were not in parallel with those in serum FFA concentrations in both groups of rats. At $03.00 \mathrm{~h}$, although FFA release rate was relatively high in both groups, serum FFA concentration was the lowest within the $24-\mathrm{h}$ cycle. This might be related in part to decreased voluntary activity at this time point in rats either meal-fed or fed ad libitum (27), providing lowered concentrations of serum lipolytic hormones and a subsequently decreased lipolysis in adipose tissues. However, some discrepancies between glycogen stores in adipose tissues, rates of FFA release by fat cells and serum FFA concentrations were not well explained.

We showed clear evidences for the enhanced lipolytic activity of fat cells in meal-fed rats versus ad libitum fed rats over an almost 24-h feeding cycle. This finding supports that of Braun et al.(6) who have described a higher lipolytic response to epinephrine in the epididymal adipose tissue from $2-\mathrm{h}$ meal-fed rats. The present study demonstrated that fat cells of meal-fed rats were able to respond at a significantly greater extent to lipolytic action of either epinephrine, an adenylate cyclase activator, or theophylline, a phosphodiesterase inhibitor, than those of rats fed ad libitum. This indicates that the fat cells of meal-fed rats could respond to upmost cAMP levels to a greater extent, as compared with those of rats fed ad libitum. Thus, metabolic activity of cAMP-hormone sensitive lipase system in fat cells might be significantly increased with meal feeding.

The lipolytic activity of fat cells from normal rats has been reported to elevate with increasing cell size $(35,36)$ or to not be influenced by cell size (37). However, fat cells from cold-adapted $(38)$ and exercise-trained $(39,40)$ rats have been indicated to exhibit a higher activity of epinephrine-stimulated lipolysis with decreasing cell size. In the present study, as previously observed by Braun et al.(7), meal-fed rats contained smaller epididymal fat cells than ad libitum fed rats. Thus, fat cells of meal-fed rats in this study seemed to have similar cellularity and lipolytic function with those of cold-adapted and trained rats.

In conclusion, the present study clearly demonstrated that lipolytic activity of isolated fat cells from rats showed diurnal changes during the 24-h feeding cycle, and the rhythm and its amplitude were much influenced by feeding pattern. Furthermore, the lipolytic activity of fat cells was significantly increased by meal feeding 2-h per day. Thus, it could be said that meal feeding may enhance lipid metabolism of adipose tissue in rats, involving lipolysis as well as lipogenesis which has been frequently reported. This seems to give a new idea for realizing the discrepancy that, although the increased body fat accumulation in meal-fed rats has been reported by pioneer workers $(41-43)$ in this interesting field of nutrition, many workers $(20,44-46)$ have not been able to reconfirm such a finding.

This work was presented in part at the 20th Meeting of the Japanese Conference of Biochemistry of Lipids, Tokyo, July, 1978. This work was partly supported by a Grant from 
the U.S.-Japan Cooperative Medical Science Program for Malnutrition.

\section{REFERENCES}

1) Leveille, G. A. (1970): Adipose tissue metabolism: influence of periodicity of eating and diet composition. Fed. Proc., 29, 1294-1301.

2) Leveille, G. A., and Chakrabarty, K. (1967): Diurnal variations in tissue glycogen and liver weight of meal-fed rats. J. Nutr., 93, 546-554.

3) Kimura, T., Maji, T., and Ashida, K. (1970): Periodicity of food intake and lipogenesis in rats subjected to two different feeding plans. J. Nutr., 100, 691-697.

4) Leveille, G. A. (1967): Control of lipogenesis in adipose tissue of fasted and fed mealfed rats. J. Nutr., 92, 460-466.

5) Ip, M. M., Ip, C., Tepperman, H. M., and Tepperman, J. (1977): Effect of adaptation to meal-feeding on insulin, glucagon, and the cyclic nucleotide-protein kinase system in rats. J. Nutr., 107, 746-755.

6) Braun, T., Fabry, P., and Kazdova, L. (1966): Lipolytic effect of adrenalin and adipose tissue of rats in relation to the feeding pattern. Cs. fisiol., 15, 523-524.

7) Braun, T., and Fabry, P. (1969): Adaptation to the pattern of food intake: changes in adipose tissue. Adv. Enzyme Regul., 7, 49-55.

8) Suzuki, M. (1980): Automated feeding apparatuses, in Nutritional Experiments Using Small Animals, ed. by Hosoya, N., Innami, S., and Gotoh, S., Daiichi-shuppan, Tokyo, pp. 36-39.

9) Rodbell, M. (1964): Metabolism of isolated fat cells. J. Biol. Chem., 239, 375-380.

10) Takeda, S., and Nakaya, Y. (1977): Isolated fat cells, in Hormones (1), Seikagaku Jikken Koza (in Japanese), Vol. 16, ed. by Japanese Society of Biochemistry, Tokyokagaku-dōjin, Tokyo, pp. 86-92.

11) Kawade, M. (1972): Free fatty acid. Rinsho Byori (Jpn. J. Clin. Pathol.), Suppl., 19, 66-73.

12) Lumbert, M., and Neish, A. C. (1950): Rapid method for estimation of glycerol in fermentation solution. Canad. J. Res., 28, 83-89.

13) Hartree, E. F. (1972): Determination of protein: a modification of the Lowry method that gives a linear photometric response. Anal. Biochem., 48, 422-427.

14) Bergmeyer, H. V., and Bert, E. (1974): D-Glucose; Determination with glucose oxidase and peroxidase, in Methods of Enzymatic Analysis, Vol. 3, ed. by Bergmeyer, H. U., Academic Press Inc., New York and London, pp. 1212-1215.

15) Wieland, O. (1974): Glycerol: UV-method, in Methods of Enzymatic Analysis, Vol. 3, ed. by Bergmeyer, H. U., Academic Press Inc., New York and London, pp. 1404-1409.

16) Philippens, K. M. H., Mayershbach, H. V., and Sheving, L. E. (1977): Effects of the scheduling of meal-feeding at different phases of the circadian system in rats. J. Nutr., 107, 176-193.

17) Romsos, D. R., and Leveille, G. A. (1974): Effect of meal frequency and diet composition on glucose tolerance in the rat. J. Nutr., 104, 1503-1512.

18) Vrana, A., Fabry, P., and Braun, T. (1969): Insulin sensitivity of adipose tissue and of diaphragm in rats adapted to periodic hyperphagia. Diabetologia, 5, 300-303.

19) Wiley, J. H., and Leveille, G. A. (1970): Significance of insulin in the metabolic adaptation of rats to meal ingestion. J. Nutr., 100, 1073-1080.

20) Reiser, S., and Hallfrisch, J. (1977): Insulin sensitivity and adipose tissue weight of rats fed starch or sucrose diets ad libitum or in meals. J. Nutr., 107, 147-155.

21) Suzuki, M., Hashiba, N., and Kanno, S. (1981): Effect of various feeding patterns on

Vol. 29, No. 4, 1983 
circadian rhythm of voluntary running activity in rats. Health and Sport Sci., Univ. Tsukuba, 4, 155-169.

22) Munro, H. N., Clark, C. M., and Goodlad, G. A. J. (1961): Loss of liver glycogen after administration of protein or amino acids. Biochem. J., 80, 453-458.

23) Peret, J., Macaire, I., and Chang, M. (1973): Schedule of protein ingestion, nitrogen and energy utilization and circadian rhythm of hepatic glycogen, plasma corticosterone and insulin in rats. J. Nutr., 103, 866-874.

24) Peret, J., Foustuck, S., Chanez, M., Bois-Joyeux, B., and Assan, R. (1981): Plasma glucagon and insulin concentrations and hepatic phosphoenolpyruvate carboxykinase activities during and upon adaptation of rats to a high protein diet. J. Nutr., 111, 11731184.

25) Yokoyama, M., Tanaka, T., Murakami, Y., and Hayashi, S. (1976): Mechanisms of the specific dynamic action of ingested protein, with reference to loss of liver glycogen after casein intake. Clin. Chem. Symp., 16, 216-217.

26) Tanaka, T. (1978): The mechanism of specific dynamic effect of ingested protein. Eiyo To Shokuryo (J. Jpn. Soc. Food Nutr.), 31, 1-7.

27) Langhans, W., Geary, N., and Scharrer, E. (1982): Liver glycogen content decreases during meals in rats. Am. J. Physiol., 243, R450-R453.

28) Leveille, G. A., and Hanson, R. W. (1965): Influence of periodicity of eating on adipose tissue metabolism in the rat. Canad. J. Physiol. Pharmacol., 43, 857-868.

29) Leveille, G. A. (1966): Glycogen metabolism in meal-fed rats and chicks and the time sequence of lipogenic and enzymatic adaptive changes. J. Nutr., 90, 449-459.

30) Barash, V., Schramm, H., and Gutman, A. (1977): Regulation of glycogen synthetase and phosphorylase activities in rats adipose tissue. Biochim. Biophys. Acta, 481, 86-95.

31) Brodie, B. B., Krishna, G., and Hynie, S. (1969): On the role of adenyl cyclase in the regulation of lipolysis in fasting. Biochem. Pharmacol., 18, 1129-1134.

32) Gorman, R. R., Tepperman, H. M., and Tepperman, J. (1972): Effects of starvation, refeeding, and fat feeding on adipocyte ghost adenyl cyclase activity. J. Lipid Res., 13, 276-280.

33) Cooper, B., Weinblatt, F., and Gregerman, R. I. (1977): Enhanced activity of hormonesensitive adenylate cyclase during dietary restriction in the rat. J. Clin. Invest., 59, 467474.

34) Voughan, M., and Steinberg, D. (1965): Glyceride biosynthesis, glyceride breakdown in adipose tissue: mechanisms and regulation, in Handbook of Physiology, Section 5, Adipose Tissue, ed. by American Physiological Society, Washington D.C., pp. 293-351.

35) Reardon, M. E., Goldrich, R. B., and Fidge, N. H. (1973): Dependence of rates of lipolysis, esterification, and free fatty acid release in isolated fat cells on age, cell size and nutritional states. J. Lipid Res., 14, 319-326.

36) Hansen, F. M., Nielsen, J. H., and Gliemann, J. (1974): The influence of body weight and cell size on lipogenesis and lipolysis of isolated rat fat cells. Eur. J. Clin. Invest., 4, 411-418.

37) Hartman, A. D., Cohen, A. I., Richard, C. J., and Hsu, T. (1971): Lipolytic response and adenyl cyclase activity of rat adipocytes as related to cell size. J. Lipid Res., 12, 498505.

38) Therriault, D. G., Hubbard, R. W., and Mellin, D. B. (1969): Endocrine control of fat mobilization in the isolated fat cells of cold-adapted rats. Lipids, 4, 413-420.

39) Askew, E. W., Huston, R. L., Plopper, C. G., and Hecker, A. L. (1975): Adipose tissue cellularity and lipolysis. J. Clin. Invest., 56, 521-529.

40) Askew, E. W., and Hecker, A. L. (1976): Adipose tissue cell size and lipolysis in the rat: 
response to exercise intensity and food restriction. J. Nutr., 106, 1351-1360.

41) Tepperman, J., and Tepperman, H. M. (1958): Effects of antecedent food intake pattern on hepatic lipogenesis. Am. J. Physiol., 193, 55-64.

42) Cohn, C., and Joseph, D. (1959): Changes in body composition attendant on force feeding. Am. J. Physiol., 196, 965-968.

43) Han, K. (1973): Effect of frequency of meal on the growth rate, nutrient digestibility, body composition, nitrogen retention and heat production of rat. Nutr. Rep. Int., 7, 9-18.

44) Stevenson, J. A. F., Feleki, V., Sziavko, A., and Beaton, J. R. (1964): Food restriction and lipogenesis in the rat. Proc. Soc. Exp. Biol. Med., 116, 178-182.

45) Ozelci, A., Romsos, D. R., and Leveille, G. A. (1978): Influence of a liquid diet and meal pattern on body weight and body fat in rats. J. Nutr., 108, 1128-1136.

46) Suzuki, M., and Chiba, K. (1983): Effects of feeding patterns on food intake and body composition of rats. Nihon Eiyō Shokuryō Gakkaishi (J. Jpn. Soc. Nutr. Food Sci.), 36, 175-183. 